\title{
Pengaruh Iklim Komunikasi dan Motivasi Terhadap Produktifitas Kerja
}

\author{
Muhammad Mansyur*
}

*Universitas Pamulang, Tangerang, Indonesia, emmansyur@yahoo.com

\section{ARTICLE INFO}

\section{Article history:}

Received 11 Maret 2020

Received in Revised 19 Maret 2020

Accepted 17 April 2020

\section{Keywords:}

Communication Climate, Motivation, Work Productivity

ABSTRACT

The purpose of this study is to perceive and rolethe influence of the communication climate and motivation to the work productivity of employees in the Center for Development and Empowerment of Educators and Business Education. This research is causality using quantitative approach with the quotation of sample is 60 personnel. Data collections used interview, observation, literature and questionnaires in the form of questions techniques. The data analysis techniques using correlation coefficients analysis, multiple regression analysis as long as variance testing using aid programme viz Microsoft Excel. These results of this research indicate that communication climate and motivation are determining factors in measuring work productivity. Optimization the level of productivity is not yet spring to the leader's range of the from their subordinates in the communication that is not running smoothly and added to the rewards received by employees that are not comparable, which causes a decrease in employee motivation.

Tujuan dari penelitian ini adalah untuk mengetahui dan mempelajari pengaruh iklim komunikasi dan motivasi terhadap produktivitas kerja karyawan di Pusat Pengembangan dan Pemberdayaan Pendidik dan Pendidikan Bisnis. Penelitian ini bersifat kausalitas dengan menggunakan pendekatan kuantitatif dengan jumlah sampel sebanyak 60 orang. Pengumpulan data menggunakan wawancara, observasi, literatur dan kuesioner dalam bentuk teknik pertanyaan. Teknik analisis data menggunakan analisis koefisien korelasi, analisis regresi berganda selama pengujian varians menggunakan program bantuan yaitu Microsoft Excel. Hasil penelitian ini menunjukkan bahwa iklim komunikasi dan motivasi merupakan faktor penentu dalam mengukur produktivitas kerja. Optimalisasi tingkat produktivitas belum muncul ke jajaran pemimpin dari bawahan mereka dalam komunikasi yang tidak berjalan lancar dan ditambahkan ke penghargaan yang diterima oleh karyawan yang tidak sebanding, yang menyebabkan penurunan motivasi karyawan.

AKUISISI : Jurnal Akuntansi

Website : http://www.fe.ummetro.ac.id/ejournal/index.php/JA

This is an open access article distributed under the terms of the Creative Commons Attribution 4.0 International License, which permits unrestricted use, distribution,

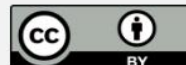
and reproduction in any medium, provided the original work is properly cited.

* Corresponding author. 


\section{PENDAHULUAN}

Organisasi merupakan suatu sistem kerja yang melibatkan berbagai komponen yang saling berinteraksi dan saling berketergantungan satu sama lainnya untuk mencapai tujuan bersama. Saling ketergantungan dan interaksi antar individu dapat diwujudkan melalui komunikasi diantara anggota organisasi dan adanya kerelaan untuk menyumbangkan tenaga dan pikiran (Sobirin, 2015, hal. 1.3). Peranan komunikasi antar individu ini sangatlah penting untuk menumbuhkan dan mendorong motivasi yang kuat dalam diri para anggota organisasi untuk berkarya lebih tekun, terutama komunikasi antar sesama anggota organisasi dan komunikasi antar pimpinan dan bawahan (Toha \& Darmanto, 2016, hal. 6.26).

Hubungan komunikasi yang sangat baik antara sesama anggota organisasi akan menumbuhkan suatu ikatan persaudaraan dan sikap saling melindungi dan saling membantu, sehingga para anggota organisasi akan merasa adanya suatu ikatan untuk menjaga dan meningkatkan hasil daya atau produktivitas organisasi (Prabawa \& Supartha, 2018). Hubungan antara pimpinan dan bawahan juga dapat menjadi harmonis dengan adanya komunikasi yang sifatnya dua arah atau timbal baik, komunikasi pimpinan kepada bawahan/anggota organisasi/pegawai dapat dilakukan dengan jalan menjelaskan kepada mereka apa yang harus dilakukan, memberi hasil penilaian tentang pelaksanaan tugas masing-masing dan cara-cara yang dapat ditempuh untuk meningkatkan prestasi kerja dimasa yang akan datang (Siagian, 2016, hal. 91). Aktivitas komunikasi menurut Wayne dan Faules merupakan iklim komunikasi yang bentuknya dapat berupa komunikasi dari atasan kepada bawahan (downward communication), dari bawahan kepada atasan (upward communication), komunikasi sesama bawahan (horizontal communication) dan komunikasi antar pribadi baik yang bersifat formal maupun informal (Puspanidra, 2016).

Pimpinan organisasi bertugas menumbuh-kembangkan motivasi para pegawainya agar dapat menjadi sumber daya mausia yang memiliki motivasi yang tinggi. Pengembangan motivasi sumber daya manusia merupakan hal yang sangat rumit, sebab baik pimpinan maupun karyawan berbedabeda dalam pola berfikir, latar belakang kehidupan para individu, maupun motivasi kerja masingmasing individu dalam berkarya (Rivai, 2015, hal. 406). Kondisi ini disebabkan oleh perubahan ataupun pergeseran pola komsumsi, harga diri, pendidikan, tingkat persaingan dan tujuan organisasi yang bersumber dari pimpinan maupun karyawan, sehingga dapat menimbulkan adanya perbedaan dalam motivasi mereka satu sama lain (Handayani, 2016).

Setiap pegawai mempunyai tanggungjawab pribadi untuk mengembangkan diri. Selama masih memungkinkan setiap pegawai tentu memiliki keinginan untuk meningkatkan pengetahuan, keterampilan dan mengubah perilaku ke arah lebih baik sesuai dengan perkembangan (Warouw, Sumayku, \& Tumbel, 2017). Disinilah letak pentingnya motivasi kerja bagi pegawai yang akan menghasilkan produktivitas kerja dan loyalitas serta prestasi yang dibutuhkan oleh organisasi. Motivasi kerja ini sangat dipengaruhi oleh berbagai hal yang terjadi, seperti kesejahteraan pribadi, iklim hubungan antar manusia, jenis kerja yang terlibat, lingkungan kerja yang bagus, pekerjaan yang menarik dan prospek yang nyata bagi pengembangan pribadi di masa sekarang dan masa yang akan datang (Lumentut, Pantow, \& Waleleng, 2017). Dari pernyataan tersebut di atas, komunikasi menjadi komponen terpenting dalam suatu organisasi dan peran motivasi para individu yang terlibat di dalamnya atau sumber daya manusia yang ada dalam suatu organisasi. 
Keberhasilan membangun jaringan atau ikatan komunikasi yang kuat antar sesama anggota organisasi ataupun antara pimpinan dan bawahanpada gilirannya akan mendorong individu untuk secara maksimal menggunakan potensi dirinya untuk mencapai tujuan bersama yang telah ditetapkan oleh organisasi (Purbaningrum, 2019, hal. 5.8). Harmonisasi yang ada melalui kerjasama di antara anggota organisasi ditambah dengan tumbuhnya motivasi yang kuat pada individu/pegawai untuk menghasilkan produktivitas yang tinggi dan berkualitas akan semakin meningkatkan perkembangan organisasi. Dengan demikian kehidupan organisasi sepenuhnya tergantung pada kesediaan sumber daya manusia untuk menyumbangkan tenaga dan pikiran dalam sistem kerjasama (Sobirin, 2015, hal. 2.6-2.7).

Iklim komunikasi tidak terlepas dari hubungan kerja antar pimpinan dan bawahan yang melibatkan interaksi diantara sumber daya manusia itu untuk memberi hasil penilaian tentang pelaksanaan tugas dalam rangka meningkatkan prestasi kerja atau produktivitas kerja dimasa yang akan datang. Selain itu, para pegawai juga membutuhkan iklim komunikasi yang baik dan kondusif oleh adanya perubahan sosial seperti pergeseran pola komsumsi, harga diri, pendidikan, tingkat persaingan dan tujuan organisasi yang tertuang dalam hierarki kebutuhan seseorang dalam Teori Motivasi (Abraham Maslow (1943-1970). Dengan demikian, kedua faktor di atas menjadi penting untuk dipahami yang mempengaruhi produktivtias karyawan seperti halnya pada Pusat Pengembangan dan Pemberdayaan Pendidik dan Tenaga Kependidikan (PPPPTK) Bisnis dan Pariwisata Jakarta yang juga memiliki persoalan terkait produktivitas karyawan.

PPPTK Bisnis dan Pariwisata yang menyampaikan hasil pengembangan dan pemberdayaan pendidik dan tenaga kependidikan kepada Pemerintah Propinsi, Pemerintah Kabupaten, Pemerintah Kota dan instansi terkait menetapkan faktor pertama dalam penentu keberhasilan dalam menjawab permasalahan yang sedang dihadapi yaitu faktor sumber daya manusia. Adanya persaingan tenaga kerja dengan kompetensi yang tinggi dari negara lain (terlebih dengan diberlakukannya MEA), dan penawaran program yang standar dari lembaga-lembaga diklat luar negeri dengan fasilitator yang memiliki kompetensi (dianggap) lebih baik dengan pendekatan pembelajaran yang menarik dan diakui secara internasional (PPPPTK Bisnis dan Pariwisata, 2018, hal. 8-9). Penetapan standar dengan program-program yang diakui secara internasional, baik secara tatap muka maupun dengan memanfaatkan teknologi informasi dan komunikasi (TIK/ICT) atau diklat berbasis ICT tentunya membuka peluang bagi pendidik dan tenaga kependidikan dalam rangka menciptakan iklim persaingan yang lebih objektif dalam rangka mencapai produktivitas yang tinggi (PPPPTK Bisnis dan Pariwisata, 2018).

PPPPTK Bisnis dan Pariwisata sebagai organisasi kependidikan juga memiliki berbagai aspek diantaranya sarana prasarana, kurikulum, input peserta diklat, sumber dana, pendidik dan tenaga kependidikan dan kondisi sosial adalah merupakan faktor-faktor yang saling terintegrasi untuk menetukan keberhasilan upaya pencapaian tujuan pendidikan itu sendiri. Penyampaian penilaian atas hasil kerja pegawai apabila disampaikan dengan cara yang santun akan diterima dengan baik pula meskipun mungkin nilai yang diberikan tidak atau kurang bagus, sehingga menumbuhkan motivasi pegawai untuk memperbaiki kinerjanya kemudian untuk mencapai tujuan bersama yaitu berkembangnya organisasi dan para anggota di dalamnya (Handayani, 2016). Selain itu, adanya peraturan perundangan yang relevan dengan peningkatan kualifikasi, kompetensi, dan sertifikasi pendidik dan tenaga kependidikan serta kebijakan restrukturisasi kementerian dan tingginya minat guru sekolah serta tenaga kependidikan dalam mengikuti mengikuti pendidikan dan pelatihan di PPPPTK Bisnis dan Pariwisata, khususnya yang diusulkan dari SMK (PPPPTK Bisnis dan 
Pariwisata, 2018, hal. 10-11). Di samping itu, peningkatan secara berkala atas alokasi biaya pendidikan yang mencapai $20 \%$ dari besaran APBN diharapkan berbanding lurus dan menjadi motivasi tersendiri bagi guru dan tenaga kependidikan untuk meningkatkan produktivitasnya dalam rangka peningkatan mutu pendidikan.

Lembaga yang ditugaskan dalam pengembangan dan pemberdayaan pendidik dan tenaga kependidikan yang memiliki legalitas dalam pelayanan peningkatan kompetensi pendidik dan tenaga kependidikan tidak ringan, sementara lembaga yang sejenis ini tersebar di seluruh Indonesia terbatas (12 institusi) dalam menjangkau pelayanannya. Sebagai gambaran bahwa keadaan pendidik dan tenaga kependidikan saat ini berjumlah 1.417 .711 orang dari berbagai jenjang dan bidang keahlian, belum termasuk tenaga administrasi dan perpustakaan serta laboran (Kementerian Pendidikan dan Kebudayaan, 2018) (Kementerian Pendidikan dan Kebudayaan, 2018).

Tabel 1 - Keadaan Pendidik dan Tenaga Kependidikan

\begin{tabular}{|c|c|c|c|}
\hline \multirow{2}{*}{ Jenjang } & \multicolumn{2}{|c|}{ Status Guru } & \multirow{2}{*}{ Jumlah } \\
\hline & Sertifikat & Belum Sertifikat & \\
\hline TK & 16.676 & 5.154 & 21.830 \\
\hline SD & 508.948 & 141.277 & 650.225 \\
\hline SMP & 239.262 & 42.216 & 281.478 \\
\hline SLB & 7.154 & 1.315 & 8.469 \\
\hline SMA & 117.669 & 20.876 & 138.545 \\
\hline SMK & 68.866 & 14.193 & 83.059 \\
\hline TOTAL & 958.575 & 225.031 & 1.183 .606 \\
\hline \multirow{2}{*}{ Jenjang } & \multicolumn{2}{|c|}{ Status Kepala Sekolah } & \multirow{2}{*}{ Jumlah } \\
\hline & Sertifikat & Belum Sertifikat & \\
\hline TK & 2.151 & 24.436 & 26.587 \\
\hline SD & 37.875 & 103.303 & 141.178 \\
\hline SMP & 8.585 & 17.239 & 25.824 \\
\hline SLB & 497 & 1.048 & 1.545 \\
\hline SMA & 3.703 & 4.571 & 8.274 \\
\hline SMK & 2.046 & 2.811 & 4.857 \\
\hline TOTAL & 54.857 & 153.408 & 208.265 \\
\hline \multirow{2}{*}{ Jenjang } & \multicolumn{2}{|c|}{ Status Pengawas Sekolah } & Jumlah \\
\hline & Sertifikat & Belum Sertifikat & Jumiant \\
\hline PAUD & 1.536 & 89 & 1.625 \\
\hline DIKDAS & 18.878 & 978 & 19.856 \\
\hline DIKMEN & 4.228 & 131 & 4.359 \\
\hline TOTAL & 24.642 & 1.198 & 25.840 \\
\hline
\end{tabular}

(Sumber: Data Tenaga Kependidikan di Indonesia, 2018)

Berdasarkan laporan tahunan (2018), Pusat Pengembangan dan Pemberdayaan Pendidik dan Tenaga Kependidikan (PPPPTK) Bisnis dan Pariwisata bahwa sejak 5 (lima) tahun terakhir, lembaga telah melaksanakan tugas dan fungsinya selaku pengembang dan pemberdayaan pendidik dan tenaga kependidikan dengan rata-rata 1.160 peserta diklat pertahunnya yang telah ditingkatkan kompetensinya melalui pendidikan dan pelatihan dan dari hasil evaluasi baik terhadap program dan 
penyelenggaraannya maupun dampak diklat bahwa walaupun menunjukan ada kenaikan namun belum optimal sejak ditargetkan sebanyak 1.890 pada tahun 2016, 5.460 pada tahun 2017 dan 11.550 pada tahun 2018 sebagaimana kualitas pelayanan akademik dan non akademik berdasarkan capaian tahunan hasil uji kompentensi Guru, Kepala Sekolah, Pengawas dan Tenaga Kependidikan lainnya (PPPPTK Bisnis dan Pariwisata, 2018, hal. 15). Di sisi lain, pelaksanaan Diklat Keahlian Ganda tahun 2018 yang alokasikan sebanyak 417 orang dan yang terealisasi sebanyak 415 orang dengan presentase sebesar $99,52 \%$. Kondisi ini tentunya jauh dari capaian target outcome atas kompetensi yang seharusnya menjadi motivasi tersendiri bagi pendidik dan tenaga pendidik.

Dari kenyataan di lapangan, menunjukan keadaan lain dari yang kita harapkan. Berdasarkan beberapa kajian, dunia usaha dan industri terhadap mutu lulusan khususnya dalam bidang bisnis dan pariwisata lebih cenderung mempekerjakan lulusan Sekolah Menengah Umum.Kedaan tersebut tidak lepas dari kualitas mutu pendidik dan Tenaga Kependidikan yang dihasilkan melalui sistem pedidikan dan pelatihannya (Damanik, Wiyono, \& Baiquni, 2016). Keadaan tersebut merupakan produk dan proses perjalanan panjang dari pertumbuhan pendidikan menengah kejuruan tersebut. Perilaku dan kebiasaan yang berjalan, tanpa disadari telah membuat sistem, sistem nilai dan sikap menerima masalah tersebut menjadi sesuatu yang wajar. Pendidikan dan pelatihan kejuruan bisnis dan pariwisata jika ingin tetap eksis maka hal tesebut tidak boleh dibiarkan. Pelaksanaan pengembangan sumber daya manusia menjadi tuntutan sendiri antara lain mengandung konsekuensi yang memerlukan perhatian, yakni menyangkut penurunan produktivitas kerja sebagai akibat cara kerja aparatur atau pegawai pada PPPPTK Bisnis dan Pariwisata, khususnya masalah pembinaan dan pelayanan (Djuwita, 2011).

Tujuan dari penelitian ini untuk mengetahui peranan dan pengaruh iklim komunikasi dan motivasi terhadap produktivitas kerja para pegawai di lingkungan Pusat Pengembangan dan Pemberdayaan Pendidik dan Tenaga Kependidikan (PPPPTK) Bisnis dan Pariwisata.

Berdasarkan teori produktivitas dikemukakan bahwa tenaga kerja dipengaruhi berbagai faktor antar lain lingkungan pekerjaan atau iklim kerja termasuk iklim komunikasi. Komunikasi bukan semata-mata untuk memberikan intruksi kepada bawahan tentang bagaimana bekerja yang efisien agar mendapatkan imbalan uang yang lebih banyak tetapi lebih dari itu, komunikasipenting untuk menginformasikan setiap perubahan yang terjadi dalam organisasi dan yang lebih penting lagi adalah melibatkan para pekerja dalam pengambilan keputusan yang menyangkut kepentingan para pekerja (Sejati, 2016). Dengan demikian upaya meningkatkan hubungan manusia (human relations) antara pimpinan dan bawahan, antara sesama pekerja, masing-masing atau secara bersama dapat meningkatkan produktivitas kerjanya. Keterlibatan antara iklim komunikasi, motivasi dan produktivitas yaitu motivasi ditimbulkan oleh adanya stimuli yang apabila dilengkapi dengan kemampuan karyawan yang memadai maka akan menghasilkan produktivitas yang tinggi (Robbins \& Coulter, 2016, hal. 64). Stimuli ini tidak hanya berbentuk pemenuhan kebutuhan ekonomi, tetapi juga iklim komunikasi dapat mempengaruhi seseorang dalam bertindak dan berperilaku yang pada akhirnya akan menimbulkan keinginan dan harapan yang mengarah kepada motivasi seseorang

Iklim komunikasi organisasi yang positif seringkali diyakini meningkatkan efektivitas komunikasi organisasi yang dapat menghasilkan produktivitas organisasi yang lebih tinggi. Adanya interaksi antar anggota organisasi baik atasan dengan bawahan maupun sesama anggota pada akhirnya membentuk iklim komunikasi (Puspanidra, 2016).Iklim Komunikasi sebagaimana dijelaskan oleh Redding terdapat 5 faktor ideal yang melekat yaitu kepercayaan, dukungan, 
partisipasi dalam pengambilan keputusan, keterbukaan dan tujuan prestasi tinggi (Haji, 2016, hal. 34).

Motivasi menjadi dasar untuk melakukan suatu tindakan yang disebabkan oleh dorongan seseorang. Motivasi merupakan usaha seseorang dalam proses menuju tercapainya suatu tujuan dengan diberi energi, diarahkan, dan berkelanjutan (Robbins \& Coulter, 2016, hal. 109). Kondisi untuk mencapai tujuan dari motifnya dilakukan dengan cara menggerakan pegawai dengan elemenelemen membangkitkan, mengarahkan, menjaga, menunjukkan intensitas, bersifat terus menerus dan adanya tujuan (Mangkunegara, 2017, hal. 93). Motivasi berasal dari kegairahan dalam bekerja dan daya seseorang untuk bergerak agar seseorang dapat melakukan kerjasama dalam bekerja secara terintegrasi dan efektif serta dengan segala upaya untuk mencapai kepuasan (Hasibuan, 2017, hal. 219). Motivasi lebih merupakan dorongan internal dan eksternal yang mempengaruhi perilaku seseorang dalam bertindak meliputi harapan, kebutuhan dan keadilan.

Menurut Teori Kebutuhan McCleland menjabarkan 3 (tiga) dimensi untuk mengukur motivasi kerja, yaitu (1) kebutuhan akan pencapaian dengan indikator antara lain pengembangan potensi, peningkatan prestasi kerja dan bertanggung jawab dalam memecahkan masalah; (2) kebutuhan akan kekuasaan dengan indikator antara lain jabatan menambah semangat kerja, capaian kesuksesan dan sosialisasi dengan rekan kerja; dan (3) kebutuhan akan afiliasi dengan indikator antara lain sense of belonging, sense of importance, sense of achievement dan sense of participation (hal. 162).

Produktivitas secara umum didefinisikan dalam hubungan antara masukan (bahan, tenaga kerja dan uang) dengan output (barang atau jasa), dimana menjadi ukur efisiensi dalam suatu perbandingan keduanya yang dibatasi oleh tenaga kerja (sebagai masukan) sementara output diukur berdasarkan satuan fisik, nilai dan bentuk (Sutrisno, 2016, hal. 99). Faktor yang mempengaruhi produktivitas kerja karyawan diantaranya adalah: sikap mental (motivasi, disiplin dan etika kerja), pendidikan dan pelatihan, keterampilan, manajemen, hubungan industrial, tingkatan penghasilan, gizi dan kesehatan, jaminan sosial, lingkungan dan iklim kerja, sarana produksi, dan kesempatan beprestasi (Saleh \& Utomo, 2018).

Produktivitas kerja diharapkan akan terlaksana secara efisien dan efektif terhadap suatu pekerjaan, sehingga sangat diperlukan dalam pencapaian tujuan akhir yang ditetapkan. Indikator untuk mengukur produktivitas kerja antara lain kemampuan, peninngkatan capaian hasil, semangat kerja, pengembangan diri, mutu, dan efisiensi (Sutrisno, 2016, hal. 104-105). Peningkatan produktivitas kerja dapat diatasi dengan adanya pemahaman yang tepat atas faktor-faktor yang menentukan keberhasilan dalam peningkatan produktivitas kerja sehubungan dengan aspek keperilakuan dan aspek-aspek teknis yang terkandung di dalamnya.

Riset ini dilatarbelakangi oleh beberapa penelitian terdahulu yaitu: (1) Pengaruh iklim komunikasi organisasi terhadap produktivitas kerja karyawan di Bank Prisma Dana Manado yang melibatkan 41 karyawan dengan teknik analisis product moment correlations dan regresi linier sederhana. Hasil penelitian menyatakan bahwa terdapat hubungan yang fungsional dan linier yang berarti antara iklim komunikasi organisasi terhadap produktivitas kerja sehingga perusahaan perlu memperhatikan iklim komunikasi organisasi untuk meningkatkan produktivitas karyawan (Pangumpia, 2013).(2) Hubungan komunikasi organisasi dan lingkungan kerja terhadap kedisiplinan kerja tahun pelajaran 2015/2016 yang melibatkan guru dan staf di MI Al-Islam Kartasura dengan teknik analisis regresi linier berganda. Hasil penelitian menjelaskan komunikasi organisasi dan lingkungan kerja sangat baik diterapkan baik para guru dan staf, apabila komunikasi organisasi dan lingkungan kerja aman, 
nyaman dan kondusif maka dengan sendirinya kedisiplinan kerja guru akan baik pula (Sejati, 2016). (3)Iklim komunikasi organisasi dalam meningkatkan motivasi kerja dengan menggunakan teori penetapan tujuan. Jenis penelitian menggunakan riset deskriptif dengan pendekatan kuantitatif yang melibatkan 60 karyawan PT. Tristan. Hasil penelitian memberi kesimpulan bahwa tingkat iklim komunikasi organisasi terbilang positif dengan dimensi supportiveness, partisipasi, kepercayaan, keterbukaan dan kinerja yang tinggi dengan persentase lebih dari 75 persen (Haji, 2016). (4) Pengaruh iklim komunikasi dan perilaku organisasi (Studi pada Pegawai Negeri Sipil Dinas Kebersihan dan Pertamanan Kota Bogor). Jenis penelitian yaitu eksplanatif menggunakan pendekatan kuantitatif dengan melibatkan 110 pegawai. Hasil penelitian menyatakan bahwa terdapat pengaruh iklim komunikasi dan perilaku organisasi terhadap kinerja dengan nilai koefisien determinasi hanya sebesar 38,9 persen (Puspanidra, 2016). (5) Pengaruh iklim organisasi dan motivasi kerja terhadap produktivitas kerja pegawai Dinas Pendidikan Kabupaten Sambas dengan jenis penelitian causal study menggunakan pendekatan kuantitatif. Hasil penelitian membuktikan pengaruh yang signifikan antara iklim organisasi, motivasi kerja terhadap produktivitas kerja baik secara simultan maupun secara parsial (Musbandi, 2017).

Model penelitian di bawah ini menjelaskan bahwa iklim organisasi dan motivasi merupakan variabel bebas yang menjelaskan pengaruhnya secara langsung terhadap variabel produktivitas kerja yang menjadi variabel dipengaruhi (dependen).

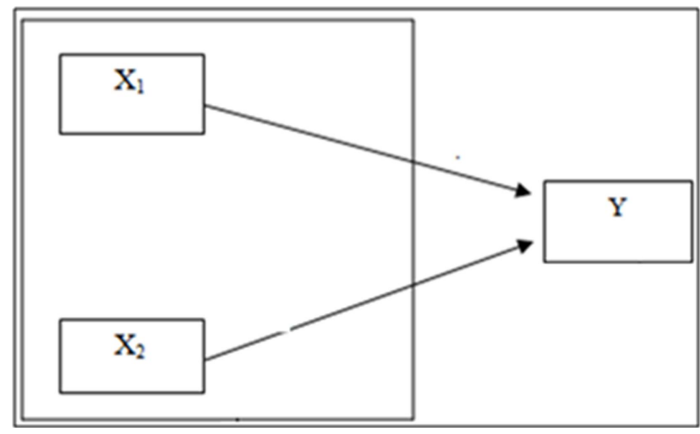

Gambar 1 - Model Penelitian

$$
\begin{array}{ll}
\mathrm{Y}=\mathrm{F}\left(\mathrm{X}_{1}, \mathrm{X}_{2}\right) \text {, dimana: } & \mathrm{Y}=\text { Produktivitas Kerja } \\
& \mathrm{X} 1=\mathrm{Iklim} \text { Komunikasi } \\
& \mathrm{X} 2=\text { Motivasi }
\end{array}
$$

\section{METODE PENELITIAN}

In this section contains methods, types of data, data sources, data collection techniques, data analysis techniques, measurement variables. Made in the form paragraphs flow and not made numbering. Statistical symbols using symbols and terminology standards eg t-test instead of thitung.

Jenis penelitian ini merupakan riset survei dengan pendekatan penelitian kuantitatif. Populasi penelitian yaitu pegawai pada Pusat Pengembangan dan Pemberdayaan Pendidik dan Tenaga Kependidikan Bisnis dan Pariwisata Jakarta sebanyak 278 orang. Pegawai merupakan PNS baik Pejabat struktrural maupun pejabat Fungsional. Latar belakang pendidikan cukup beragam mulai dari jenjang pendidikan dasar (SMP/MTs) berjumlah 104 orang, jenjang pendidikan menengah (SMA/MA dan SMK) berjumlah 71 orang maupun jenjang pendidikan Tinggi berjumlah 98 orang. Dengan golongan I berjumlah 5 orang, golangan II berjumlah 43 orang 218 orang dan golongan IV 
berjumlah 50 orang. Sampel adalah jumlah dan karakteristik yang dimiliki dan menjadi bagian dari populasi, jika populasi besar akan tidak mungkin peneliti mempelajari semua yang terdapat pada populasi, seperti adanya keterbatasan tenaga, waktu, dan pendanaan sehingga dapat menggunakan sampel yang diambil dari bagian populasi itu (Sugiyono, 2016, hal. 119-120). Penetapan sampel dapat dihitung berdasarkan ukuran metode penelitian yang digunakan, yaitu (a) metode deskriptif, minimal 10\% dari populasi dan sampel yang relatif kecil dapat menggunakan 20\%; (b) metode deskriptif korelasional minimal 30 subjek; dan (c) metode expost-facto dan metode eksperimental minimal 15 subjek per kelompok (Mahmud, 2011, hal. 59). Lebih lanjut, apabila jumlah reponden kurang dari 100 maka sampel diambil semua (penelitian populasi) sedangkan apabila jumlah responden lebih dari 100, maka pengambilan sampel 10\%-15\% atau 20\%-25\% atau lebih (Arikunto, 2016, hal. 112).

Metode pengumpulan data menggunakan teknik wawancara, pengamatan/observasi, kepustakaan dan penyebaran kuesioner dalam bentuk pertanyaan. Jumlah pertanyaan yang diajukan kepada responden untuk menggali informasi mengenai iklim komunikasi dan motivasi serta produktivitas kerja pegawai yaitu:

1. Variabel iklim organisasi meliputi kepercayaan, dukungan, partisipasi dalam pengambilan keputusan, keterbukaan dan tujuan prestasi tinggi.

2. Variabel motivasi meliputi harapan, kebutuhan dan keadilan.

3. Variabel produktivitas kerja meliputi kualitas hasil kerja, kuantitas hasil kerja, efektivitas dalam bekerja dan efisiensi dalam bekerja.

Alat pengumpulan data lebih ditekankan pada jawaban atas pertanyaan yang diajukan kepada responden dengan memberikan skor skala yang mengacu pada kuesioner Spielberger State-Trait Anxiety Inventory (STAI: Y-4) yang dikembangkan oleh Marteau TM dan Bekker H pada tahun 1992 dengan 2 (dua) jenis yaitu skala kecemasan negara (State Anxiety) dan skala kecemasan trait (Trait Anxiecy). Penelitian ini menggunakan skala (S-Anxiety), skala untuk menilai intensitas perasaan saat ini yaitu para Pendidik dan Tenaga Kependidikan dengan skala Likert dengan alternatif jawaban dan skor sebagai berikut:

1. Untuk Penilaian "Sangat", diberi skor skala 4

2. Untuk Penilaian "Cukup" diberi skor skala 3.

3. Untuk penilaian "Agak" diberi skor skala 2.

4. Untuk Penilaian "Tidak sama sekali” diberi skor skala 1

(Usnadi, Rahayu, \& Praptiwi, 2019).

Alat pengumpulan data lebih ditekankan pada jawaban atas pertanyaan yang diajukan kepada responden dengan memberikan skor skala yang mengacu pada kuesioner Spielberger State-Trait Anxiety Inventory (STAI: Y-4) yang dikembangkan oleh Marteau TM dan Bekker H pada tahun 1992 dengan 2 (dua) jenis yaitu skala kecemasan negara (State Anxiety) dan skala kecemasan trait (Trait Anxiecy). Penelitian ini menggunakan skala (S-Anxiety), skala untuk menilai intensitas perasaan saat ini yaitu para Pendidik dan Tenaga Kependidikan dengan skala Likert dengan alternatif jawaban dan skor sebagai berikut:

Teknik analisis data menggunakan:

1. Analisis Korelasi (R), digunakan untuk menilai hubungan atau keeratan antara variabel bebas dengan variabelterikat dengan rumus berikut ini:

$$
\mathrm{R}=\frac{\mathrm{N} \Sigma \mathrm{XY}-\Sigma \mathrm{X} \Sigma \mathrm{Y}}{\sqrt{[\mathrm{N} \Sigma \mathrm{X} 2-(\Sigma \mathrm{X}) 2(\mathrm{~N} \Sigma \mathrm{Y} 2-(\Sigma \mathrm{Y}) 2]}}
$$


2. Analisis Regresi Linier Berganda, digunakan untuk mengetahui sifat hubungan antara variabel bebas (iklim komunikasi dan motivasi) sebagai X1 dan X2 terhadap variabel terikat (produktivitas kerja pegawai) sebagai $\mathrm{Y}$ dengan rumus persamaan berikut ini:

$\mathrm{Y}=\alpha+\beta 1 \mathrm{X} 1+\beta 2 \mathrm{X} 2+\beta \mathrm{Xn}$,

dimana $\mathrm{Y}$ adalah variabel terikat

$\alpha \quad=$ parameter konstanta

$\beta 1, \beta 2=$ koefisien prediktor

$\mathrm{X} 1, \mathrm{X} 2$ =variabel bebas

3. Analisis Varian (ANOVA) digunakan untuk menentukan apakah terdapat variasi yang menentukan selanjutnya untuk menguji perbedaan mean melalui rumus berikut ini:

$$
\mathrm{t}=\frac{\Sigma \mathrm{D}}{\sqrt{[}[\mathrm{N} \Sigma \mathrm{D} 2-(\Sigma \mathrm{D}) 2 / \mathrm{N}-1]}
$$

\section{HASIL DAN PEMBAHASAN}

\subsection{Analisis Deskripsi Data}

Responden dari penelitian ini adalah Pegawai Pusat Pengembangan dan Pemberdayaan Pendidik dan Tenaga Kependidikan Bisnis dan Pariwisata Jakarta sebanyak 278 orang, 20-25 persen dari jumlah populasi sehingga jumlah responden yang mewakili pada penelitian ini ditetapkan sebanyak 60 pegawai. Karakteristik responden dijabarkan per jenis kelamin, pendidikan, tingkat umur serta masa kerja pegawai tersebut.Berdasarkan data yang diperoleh dan telah ditabulasi, kemudian diolah dengan mempergunakan program statistik komputer Microsoft Excel diperolah hasil sebagai berikut:

Tabel 2 - Deskripsi DataVariabel Penelitian

\begin{tabular}{|c|c|c|c|}
\hline & $\begin{array}{l}\text { Nilai } \\
\text { Mean }\end{array}$ & Std. Dev Label & \\
\hline $\bar{Y}$ & 2,834 & 0,541 & rata-rata skor produktivitas \\
\hline $\mathrm{X} 1$ & 2,978 & 0,556 & rata-rata skor iklim komunikasi \\
\hline $\mathrm{X} 2$ & 2,940 & 0,559 & rata-rata skor motivasi \\
\hline$N$ of Cases $=60$ & & & \\
\hline
\end{tabular}

(Sumber: Hasil Pengolahan Data MS.Excel, 2019)

Berdasarkan hasil analisis deskripsi data variabel penelitian dapat diketahui bahwa dengan jumlah data 60, rata-rata dari nilai rata-rata produktivitas kerja pegawai di lingkungan institusi 2,834 dan standar deviasinya sebesar 0,541 , hal ini berarti keseluruhan hasil penelitian menunjukan bahwa pegawai yang menjadi subjek penelitian memiliki produktivitas kerja mendekati kategori "cukup". Rata-rata dari variabel bebas iklim komunikasi adalah 2,978 dan standar deviasinya sebesar 0,556, hal ini terlihat bahwa iklim komunikasi yang ada di lingkungan subjek penelitian juga masih dibawah kategori "cukup". Rata-rata dari variabel bebasmotivasi adalah 2,940 dan standar deviasinya sebesar 0,59 , hal ini berarti motivasi para pegawai pada subjek penelitian juga masih di bawah kategori "cukup".

Guna mendapatkan data dari variabel iklim komunikasi, motivasi kerja dan produktivitas kerja maka digunakan instrumen yang mengacu pada indikator masing-masing variabel. Berdasarkan data yang terkumpul setelah ditabulasi dan diberi skor tertinggi pada setiap responden untuk satu instrumen adalah $4 \times 20=80$,karena jumlah responden adalah 60 , maka jumlah skor tertinggi adalah $60 \times 80=4800$. Data-data yang terkumpul kemudian dilakukan pengolahan data ternyata jumlah skor 
variabel iklim komunikasi adalah 3553. Dengan demikian, iklim komunikasi yang terlaksana pada institusi adalah 3553:4800=0,74 atau sekitar 74\%. Hasil perhitungan diatas terungkap bahwa iklim komunikasi yang terbentuk pada institusi baru mencapai 74 persen. Motivasi kerja merupakan faktor pendorong yang mendukung terciptanya iklim komunikasi. Berdasarkan data yang terkumpul kemudian dilakukan pengolahan data ternyata jumlah skor variabel motivasi para pegawai sebanyak 2627 artinya $2627: 4800=0,54$ atau sekitar 54\%. Produktivitas kerja adalah variabel terikat yang dipengaruhi oleh iklim komunikasi dan motivasi menghasilkan skor 2043 artinya 2043:4800=0,42 atau sekitar $42 \%$.

\subsection{Analisis Koefisien Korelasi}

Tabel 3 - Rekapitulasi Skor Perhitungan Koefisien Korelasi

\begin{tabular}{llllllll}
\hline Rerata X1 & Rerata X2 & Rerata Y & X1.X2 & X1.X2.Y & X1 $^{2}$ & X2 $^{2}$ & $\mathbf{Y}^{\mathbf{2}}$ \\
\hline 178,65 & 176,42 & 170,06 & $\sum=543,3$ & $\sum=1592,6$ & $\sum=550,1$ & $\sum=537,2$ & $\sum=449,29$
\end{tabular}

(Sumber: Data Diolah, 2019)

Dari hasil perhitungan diperoleh:

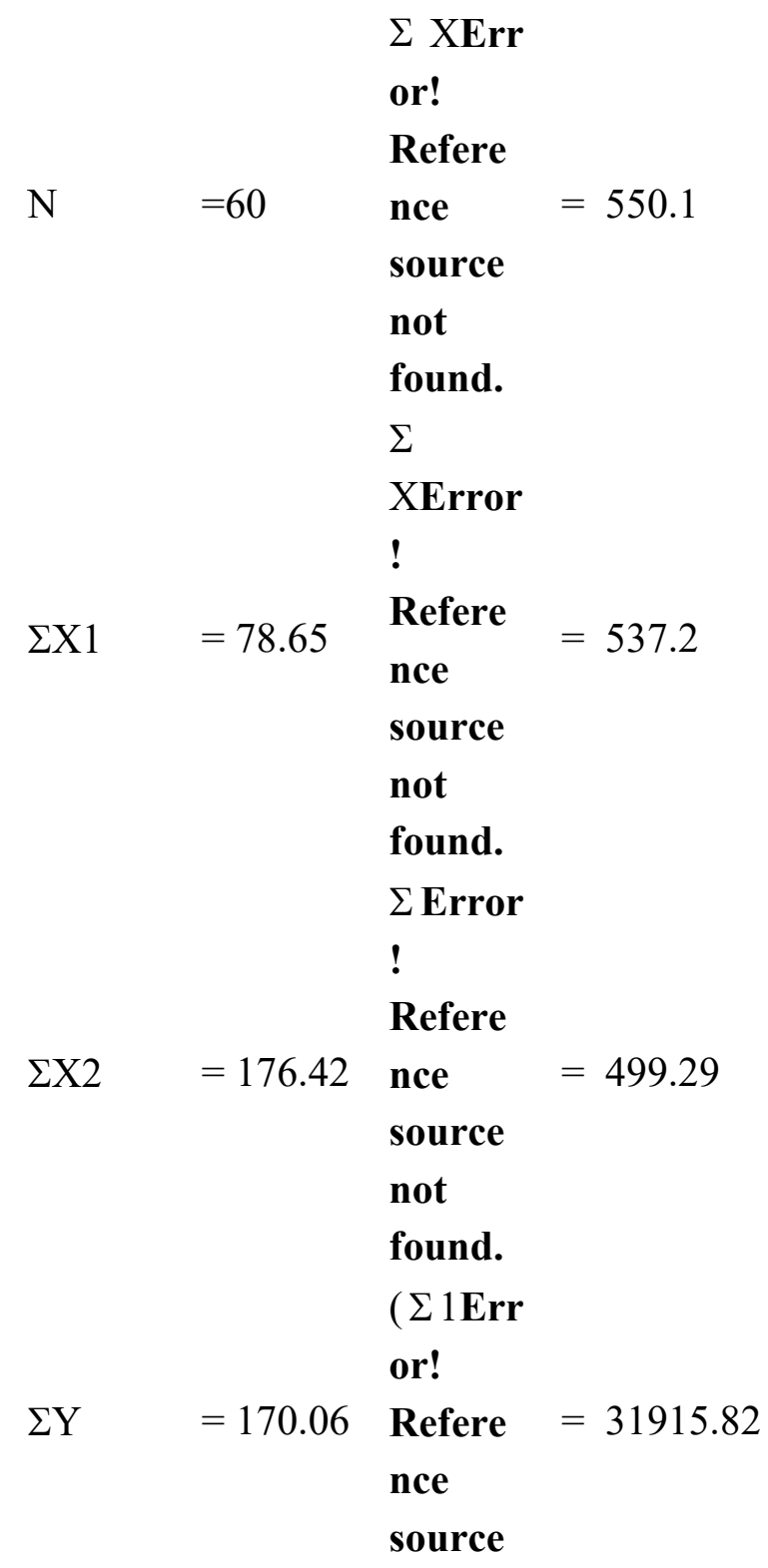




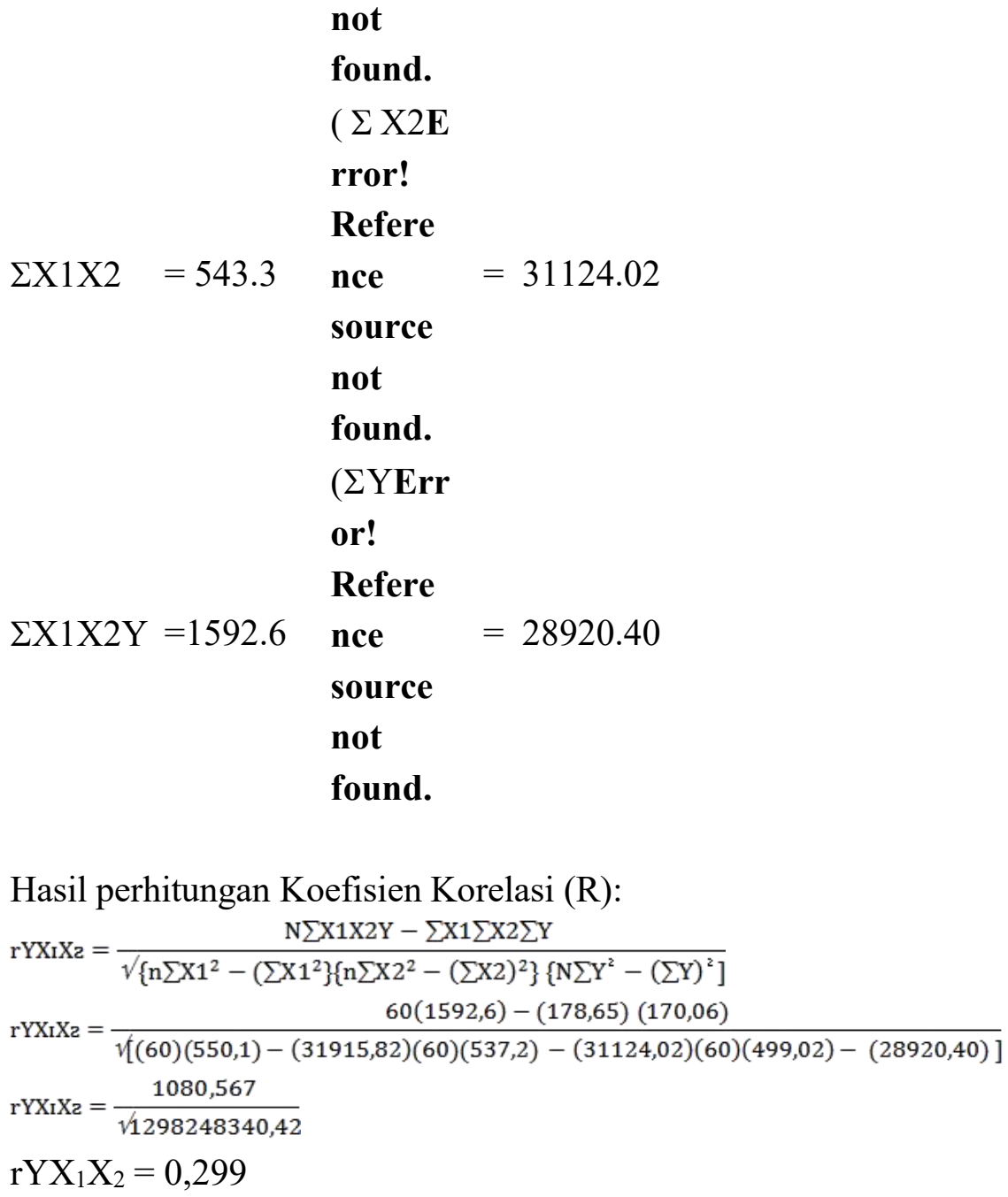

Korelasi data penelitian (hubungan antar variabel) dimana $\mathrm{X}$ sebagai variabel bebas dan $\mathrm{Y}$ sebagai variabel terikatnyapada tingkat kepercayaan (signifikansi) 5 persen dari jumlah penelitian diperoleh hasil korelasi sebagai berikut:

1. Besarnya hubungan antar variabel $\mathrm{Y}$ (produktivitas kerja pegawai dilingkungan Institusi) dengan X1 (iklim Komunikasi) dan X2 (motivasi) berdasarkan perhitungan koefisien korelasi adalah 0,299 dengan signifikansi sebesar 0,05, artinya bahwa ketiga variabel tersebut memiliki hubungan yang sangat kuat dan positif, hal ini menunjukan bahwa hubungan antara iklim komunikasi, motivasi dan produktivitas Kerja adalah nyata.

2. Koefisien determinasi variabel iklim komunikasi dan motivasi terhadap produktivitas kerja pegawai dilingkungan Institusi adalah:

$\mathrm{R}=\mathrm{r}^{2}$

$=(0,229)^{2}$ atau $=0,052$

Perhitungan diatas menunjukan bahwa seluruh variabel bebas yakni variabeliklim komunikasi dan motivasi dimasukan dalam perhitungan regresi.Angka $\mathrm{R}-$ Square $\left(\mathrm{R}^{2}\right)$ adalah 0,052 , hal ini berarti bahwa 5,2 produktivitas kerja pegawai dapat dijelaskan oleh variabeliklim komunikasi dan motivasi.

\subsection{Analisis Regresi Linier Berganda}

Dari hasil perhitungan uji-t diperoleh: 


$$
\begin{aligned}
\mathrm{t} & =\frac{r \sqrt{ }(\mathrm{n}-2)}{\sqrt{(1-\mathrm{r} 2)}} \\
& =\frac{0,299 \sqrt{ }(60-2)}{\sqrt{ }(1-0,089)} \\
& =\frac{0,299 \sqrt{ }(58)}{\sqrt{6,948}} \\
& =\frac{0,299 \times 7,616}{0,974} \\
& =\frac{2,277}{0,974} \\
\mathrm{t} & =2,338
\end{aligned}
$$

Nilai t-hitung sebesar 2,338 lebih besar $(>)$ dari nilai t-tabel $(1,19)$, artinya hasil uji hipotesis tersebut maka Ho ditolak dan Ha diterima.Pengaruh iklim Komunikasi dan Motives yang domelike kerrawang Pusant Pengembangan dan Pemberdayaan Pendidik dan Tenaga Kependidikan (PPPPTK) Bisnis dan Pariwisata - Jakarta adalah sebagai berikut:

1. Iklim Komunikasi yang terdiri dari kepercayaan, dukungan, partisipasi dalam pengambilan keputusan, keterbukaan dan tujuan mencapai prestasi (pencapaian tujuan), serta motivasi kerja berupa adanya harapan, kebutuhan dan keadilan mendapatkan imbalan pada penelitian ini sebagai variabel bebas secara bersama-sama dapat memberikan konstribusi produktivitas kerja pegawai yang dibuktikan dari uji korelasi yang memiliki hubungan dengan nilai signifikansipada tingkat kesalahan dibawah 5\%.

2. Besarnya hubungan antar variabel Y (Produktivitas Kerja) dengan X1 (Iklim Komunikasi) dan X2 (Motivasi) yang dihitung dan menghasilkan skor koefisien korelasi senilai 0,229 dengan signifikansi 0,05. Artinya kedua variabel tersebut memiliki hubungan yang cukup kuat dan signifikan serta menunjukan hubungan positif. Dengan demikian, uji hipotesis alternatif diterima karena iklim komunikasi dan motivasi memberikan pengaruh yang signifikan terhadap produktivitas kerja pegawai.

3. Seluruh uji statistik dengan program komputerMicrosoft Excel menunjukan variabel bebas mempunyai pengaruh yang signifikan terhadap variabel terikatnya dengan nilai t-hitung $>\mathrm{t}$ tabel sehingga uji hipotesis nol $\left(\mathrm{H}_{0}\right)$ dalam penelitian ini ditolak dan hipotesis alternatif $(\mathrm{Ha})$ menjadi diterima pada tingkat signifikansi di bawah $5 \%$.

4. Angka R-Square adalah 0,052, artinya 5,2 persen produktivitas kerja pegawai pada institusi dapat dijelaskan oleh variabel iklim komunikasi dan motivasi sedangkan sisanya (100\% - 5,2\%) sebesar 94,8 persen dipengaruhi oleh faktor lain. Apabila iklim komunikasi yang ada berjalan lancar dan motivasi pegawai sangat tinggi, maka produktivitas kerja akan semakin tinggi. Dan sebaliknya, jika semakin rendah komunikasi dan semakin tidak adanya motivasi para pegawai dalam bekerja maka produktivitas yang dihasilkan juga akan semakin menurun.

\subsection{Pembahasan}

Hasil analisis atas uji koefisien korelasi, analisis regresi berganda atashubunganiklim komunikasi, motivasi terhadap produktivitas kerja pagawai menghasilkan skor koefisien korelasi sebesar 0,229 dan skor uji-t sebesar2,229 lebih besar dibandingkan dengan nilai $\mathrm{t}_{\text {-tabel }}(1,19)$ sehingga menolak $\mathrm{H}_{0}$ dan menerima $\mathrm{H}_{1}$, artinya terdapat pengaruh positif dan signifikan iklim komunikasi, motivasi 
terhadap produktivitas kerja pegawai Pusat Pengembangan dan Pemberdayaan Pendidik dan Tenaga Kependidikan (PPPPTK) Bisnis dan Pariwisata - Jakarta. Hasil pengolahan data dan penerimaan hipotesis alternatif dengan penelitian sebelumnya yaitu terdapat hubungan yang fungsional dan linier yang berarti antara iklim komunikasi organisasi terhadap masing-masing produktivitas kerja, motivasi kerja maupun kinerja (Pangumpia, 2013; Haji, 2016; Puspanidra, 2016; Musbandi, 2017). Iklim komunikasi yang efektif dengan melibatkan seluruh kelompok anggota dan ketua akan memperoleh banyak manfaat dipandang akan lebih efektif dalam rangka menjamin kelancaran penugasan yang diberikan (Desrianita, 2018). Sementara hubungan motivasi kerja terhadap produktivitas kerja juga mengkonfirmasi penelitian dengan hasil bahwa terdapat pengaruh yang signifikan antara motivasi kerja terhadap produktivitas kerja pegawai Dinas Pendidikan di Kabupaten Sambas. Iklim komunikasi dan motivasi kerja merupakan salah satu faktor penentu dalam mengukurproduktivitaskerja. Faktor motivasi juga hendaknya diperhatikan dengan lebih seksama sebagai bagian dari iklim komunikasi organisasi terhadap kerjasama antar rekan kerja dalam rangka untuk meningkatkan produktivitas karyawan.

\section{SIMPULAN}

Penelitian ini dilakukan untuk dengan maksud untuk mengetahui peranan dan pengaruh iklim komunikasi dan motivasi terhadap produktivutas kerja para pegawai di lingkungan Pusat Pengembangan dan Pemberdayaan Pendidik dan Tenaga Kependidikan Bisnis dan Pariwisata.Berdasarkan hasil analisis koefisien korelasi dan analisis regresi linier berganda dengan bantuan program komputer Microsoft Excel menghasilkan simpulan penelitian berikut ini:

1. Iklim Komunikasi yang lancar dan adanya motivasi yang tinggi dapat memberikan pengaruh positif terhadap meningkatkan produktivitas kerja pegawai,hal ini dapat dilihat dari hasil pengujian korelasi pearson, dimana iklim komunikasi dan motivasi memberikan kontribusi yang sangat besar terhadap produktivitas kerja.

2. Pengaruh iklim komunikasi dan motivasi pegawai terhadap kinerja mereka sangat signifikan, apabila iklim komunikasi berjalan lancar dan motivasi pegawai yang dihasilkan juga tinggi maka produktivitas akan meningkat.Dan sebaliknya, jika iklim komunikasi tidak berjalan lancar serta motivasi kerja pegawai rendah, maka produktivitasnya akan rendah.

3. Belum optimalnya tingkat produktivitas disebabkan masih adanya jarak pimpinan dengan bawahannya dalam komunikasi yang terjalin tidak berjalan lancar dan ditambahkan dengan penghargaan yang diterima karyawan tidak sebanding yang menyebabkan menurunnyamotivasi pegawai.

Saran yang dapat disampaikan melalui penelitian ini adalah:

1. Agar produktivitas kerja pegawai meningkat maka iklim komunikasi dan motivasi senantiasa ditumbuhkembangkan baik terhadap atasan maupun bawahan.

2. Untuk dapat meningkatkan motivasi kerja dalam menghasilkan produktivitas kerja yang maksimal sesuai yang diharapkan maka pihak manajemen perlu mengkaji factor-faktor lain yang mungkin mempengaruhi selain iklim komunikasi. 
3. Pihak manajemen seyogyanya dapat meningkatkan lagi iklim keterbukaan agar komunikasi dapat berjalan lancar, demikian pula faktor imbalan yang masih memerlukan pengkajian yang lebih terbuka.

\section{Ucapan Terima Kasih}

Saya mengucapkan terima kasih pada Tuhan Yang Maha Esa atas rahmat dan karunia-Nya sehingga artikel ini dapat diselesaikan. Penulis juga mengucapkan terima kasih kepada Pusat Pengembangan dan Pemberdayaan Pendidik dan Tenaga Kependidikan Bisnis dan Pariwisata - Jakarta, Universitas Pamulang dan Universitas Muhammadiyah Metro yang memberi kesempatan untuk melakukan penelitian serta masukan-masukan dari editor dan reviewer yang banyak dan sangat berharga sekali dalam penyempurnaan isi artikel mengenai manajemen sumber daya manusia (MSDM).

\section{DAFTAR PUSTAKA}

Arikunto, S. (2016). Prosedur Penelitian Suatu Pendekatan Praktik. Jakarta: Rineka Cipta.

Damanik, J., Wiyono, D., \& Baiquni, M. (2016). Kompetensi Pendidik Bidang Kepariwisataan Di Pulau Lombok. Jurnal Ilmu Pendidikan Universitas Negeri Malang , 22 (2), 108-116.

Desrianita, D. (2018). Iklim Komunikasi pada Komunitas Trashbag Palu. Tadulako Humaniora Journal , 1 (3), 56-80.

Djuwita, T. M. (2011). Pengembangan Sumber Daya Manusia. MANAJERIAL , 10 (19), 15-21.

Haji, M. R. (2016). Iklim Komunikasi Organisasi Dalam Meningkatkan Motivasi Kerja. FISIP. Banten: Universitas Sultan Ageng Tirtayasa.

Handayani, S. (2016). Upaya Peningkatan Motivasi Kerja Pada Perusahaan Jasa Konstruksi Melalui Pendekatan Teori Kebutuhan Maslow (Studi Kasus Perusahaan Jasa Konstruksi Anggota GAPENSI Kabupaten Kebumen). Prosiding Interdisciplinary Postgraduate Student Conference. 2nd, pp. 143-184. Yogyakarta: PPs UMY.

Hasibuan, M. S. (2017). Manajemen Sumber Daya Manusia. Edisi Revisi. Cetakan ke18, Jakarta: PT Bumi Aksara. (Vols. Cetakan ke-18). Jakarta: PT Bumi Aksara.

Kementerian Pendidikan dan Kebudayaan. (2018). Data Tenaga Kependidikan. Pusat Data dan Informasi. Jakarta: Kementerian Pendidikan dan Kebudayaan.

Lumentut, G. F., Pantow, J. T., \& Waleleng, G. J. (2017). Pola Komunikasi Pemimpin Organisasi Dalam Meningkatkan Motivasi kerja Anggota di LPM (Lembaga Pers Mahasiswa) Inovasi UNSRAT. e-journal “Acta Diurna”, VI (1).

Mahmud. (2011). Metode Penelitian Pendidikan. Bandung: Pustaka Setia.

Mangkunegara, A. A. (2017). Manajemen Sumber Daya Manusia. Bandung: Remaja Rosdakarya.

Musbandi, A. (2017). Pengaruh Iklim Organisasi Dan Motivasi Kerja Terhadap Produktivitas

Kerja Pegawai Dinas Pendidikan Kabupaten Sambas. Fakultas Perguruan dan Ilmu Pendidikan. Pontianak: Universitas Tanjungpura.

Pangumpia, F. (2013). Pengaruh Iklim Komunikasi Organisasi Terhadap Produktivitas Kerja Karyawan Di Bank Prisma Dana Manado. Journal "Acta Diourna" , II (2).

PPPPTK Bisnis dan Pariwisata. (2018). Laporan Akuntabilitas Kinerja P4TK BISPAR Tahun 2018. Dirjen Guru dan Tenaga Kependidikan. Jakarta: Kemendikbud.

Prabawa, I. M., \& Supartha, I. W. (2018). Meningkatkan Produktivitas Karyawan Melalui 
Pemberdayaan, Kerja Sama Tim Dan Pelatihan Di Perusahaan Jasa. E-Jurnal Manajemen Unud , 7 (1), 497- 524.

Purbaningrum, D. (2019). Komunikasi Organisasi (BMP); 1-9 / SKOM4329 (Cetakan Pertama) (3 ed.). Tangerang Selatan: Universitas Terbuka.

Puspanidra, T. (2016). Pengaruh Iklim Komunikasi dan Perilaku Organisasi (Studi pada Pegawai Negeri Sipil Dinas Kebersihan dan Pertamanan Kota Bogor). WAHANA , 1 (12), 4-13.

Rivai, V. (2015). Manajemen Sumber Daya Manusia Untuk Perusahaan: Dari Teori ke Praktik (3 ed.). Jakarta: PT. Raja Grafindo Persada.

Robbins, S. P., \& Coulter, M. (2016). Manajemen (Jilid 1 dan 2) (13 ed.). (B. Sabran, \& W. Hardani, Trans.) Jakarta: Erlangga.

Saleh, A. R., \& Utomo, H. (2018). Pengaruh Disiplin Kerja, Motivasi Kerja, Etos Kerja Dan Lingkungan Kerja Terhadap Produktivitas Kerja Karyawan Bagian Produksi DI PT. Inko Java Semarang. Jurnal Ilmiah Among Makarti , 11 (21), 28-50.

Sejati, S. R. (2016). Hubungan Komunikasi Organisasi dan Lingkungan Kerja Terhadap Kedisiplinan Kerja Guru di MI Al Islam Kartasura Tahun Pelajaran 2015/2016. Pascasarjana. Surakarta: Institut Agama Islam Negeri (IAIN).

Siagian, S. P. (2016). Teori dan Praktek Kepemimpinan (ISBN: 9789795181699 ed.). Jakarta: Rineka Cipta.

Sobirin, A. (2015). Buku Materi Pokok (BMP) Perilaku Organisasi (EKMA5101). Tangerang Selatan: Universitas Terbuka.

Sugiyono. (2018). Metode Penelitian Evaluasi: Pendekatan Kuantitatif, Kualitatif, dan Kombinasi. Bandung: CV. Alfabeta.

Sugiyono. (2016). Metode Penelitian Kombinasi (Mixed Methods). (M. Sutopo, Ed.) Bandung: CV. Alfabeta.

Sutrisno, E. (2016). Manajemen Sumber Daya Manusia Cetakan Ke-8. Jakarta: Kencana Prenada Media Group.

Toha, M., \& Darmanto. (2016). Buku Materi Pokok ADPU4431/ Perilaku Organisasi (Cetakan Keempat) (2 ed.). Tangerang Selatan.

Usnadi, U., Rahayu, U., \& Praptiwi, A. (2019). Kecemasan Preoperasi pada Pasien di Unit One Day Surgery (ODS). Jurnal Keperawatan 'Aisyiyah , 6 (1), 75-87.

Warouw, C., Sumayku, S. M., \& Tumbel, T. M. (2017). Pengaruh Lingkungan Kerja Terhadap Motivasi Kerja Pada PT BPR Prisma Dana Manado. Jurnal Administrasi Bisnis (JAB) , V (005), 1-8. 